\title{
Diversity and dispersion patterns of echinoderms in Babanlagan, Talisayan, Misamis Oriental, Philippines
}

\author{
Mara Elena J. Llacuna', Angelo Mark P. Walag' ${ }^{2 *}$, Elaine A. Villaluz ${ }^{3}$ \\ ${ }^{1}$ St. Mary's Academy of Talisayan, Talisayan, Misamis Oriental, Philippines \\ ${ }^{2}$ Department of Science Education, Mindanao University of Science and Technology, Cagayan de Oro City, Philippines \\ ${ }^{3}$ Department of Biology, Xavier University - Ateneo de Cagayan, Cagayan de Oro City, Philippines \\ *Corresponding author, E-mail: angelowalag@must.edu.ph
}

\begin{abstract}
Echinoderms are fundamentally good indicators of health and status of coralline communities in marine waters. In this study, the diversity and distribution of echinoderm species were determined in Babanlagan, Talisayan, Misamis Oriental. In total, 387 individuals were collected coming from classes Echinoidea, Holothuroidea, Asteroidea, and Ophiuroidea. The majority of individuals collected were Protoreaster nodusus, which is a good indicator of reef health while the least abundant echinoderm species was Acanthaster planci. The pattern of distribution of majority of echinoderms was a clumped distribution while the other groups followed regular/uniform distribution, which may be due to limited dispersal ability and availability and available food sources. Moderate species diversity was also observed and species were rather similar in abundance, shown by the evenness index. This suggests good marine health, even under the threat of gleaning activities, active fishing, and habitat destruction. It is recommended that follow-up studies are conducted especially regarding monitoring of echinoderm species, to further assess the health of the intertidal zone in Babanlagan, Talisayan, Misamis Oriental.
\end{abstract}

Key words: Acanthaster planci, diversity, echinoderms, Protoreaster nodusus, Philippines, sea stars.

\section{Introduction}

Echinoderms represent one of the most conspicuous, successful, and ancient phyla of invertebrates in the Animal Kingdom (Souto et al. 2014). There are 7000 known species of echinoderms and about 13000 are known to be extinct (Campbell, Reece 2008). These are all marine species and members form bottom communities from poles to the tropics. The Phylum Echinodermata is divided into four classes: Asteroidea, Echinoidea, Holothuroidea and Crinoidea. The majority of these organisms are found in benthic marine environments except for some in brackish environments (Barnes 1987). Echinoderms play a vital role in marine environments where representatives are found in almost every ecosystem. Many are keystone species, playing significant and valuable roles (Dupont et al. 2010). Thus, it is very important to study their distribution, abundance, and diversity.

The Indo-Pacific region, and particularly Philippines, is the most species rich region of echinoderms in the world (Stöhr et al. 2012). Various studies have been conducted to study the distribution and diversity of echinoderms. Along the southwest coast of India, echinoids were found to be most abundant and crinoids and ophiuroids were least abundant echinoderm groups (Rajakumar, Ebanasar 2008). Macroepibenthic echinodersms were also studied in the English Channel and Irish Sea, where 24 species were identified and high diversity was noted (Ellis, Rogers 2000). In the Philippines, a study of temperature tolerance of six intertidal echinoderms showed that these species will only survive at temperature $<35{ }^{\circ} \mathrm{C}$ (Ubaldo et al. 2007). In another study of microbenthic diversity conducted in the Gusa, Cagayan de Oro City, Philippines, it was found out that echinoderms were the second most abundant group of animals in the area (Walag, Canencia 2016). A study on Holothuridea of Tubbataha reefs, Philippines found out that the lack of human impact contributed to high diversity of sea cucumbers (Dolorosa 2015).

Human activities and physico-chemical factors such as temperature, salinity, and $\mathrm{pH}$ may affect the abundance and distribution of echinoderm and macrobenthic invertebrate species (Walag, Canencia 2016). These physico-chemical factors may affect growth rate, metabolic activity, and immune response of organisms, shown by relationships between stress and reproductive success (Lawrence, Herrera 2000). Various studies have linked physico-chemical and hydrological parameters to diversity of microbenthic invertebrates, for example, in Malaysia (Md Rawi et al. 2014).

Various stresses ranging from increasing human intervention, over exploitation and continuous degradation have threatened the diversity in coastal areas of Talisayan 
Coasts. Destructive methods of fishing, siltation and sedimentation, and pollution of marine water caused by agricultural runoff and irresponsible disposal of wastes have affected the resources in coastal areas of Talisayan. The main aim of this study is to determine the distribution and diversity of echinoderms in Babanlagan, Talisayan, Misamis Oriental, Philippines. This study specifically aimed to: (i) collect and identify echinoderm species; (ii) determine the coefficient of distribution for echinoderm species; and (iii) determine the relative abundance, species diversity, and evenness of echinoderms in Babanlagan, Talisayan, Misamis Oriental, Philippines.

\section{Materials and methods}

\section{Establishment of the study area}

The study was conducted in the intertidal zone of Babanlagan ( $\left.8^{\circ} 59^{\prime} 59^{\prime \prime} \mathrm{N}, 124^{\circ} 52^{\prime} 50^{\prime \prime} \mathrm{E}\right)$, Talisayan, which is situated in Misamis Oriental, Philippines. It is located $96.8 \mathrm{~km}$ northeast of Cagayan de Oro City between the municipalities of Balingoan and Medina. The coastline is $325 \mathrm{~m}$ and intertidal zone is 100 to $150 \mathrm{~m}$ (Fig. 1). Sampling was performed three times in September 2015 during low tide. The transect-quadrat method was used in the study. Seven transects were laid perpendicular to the shore at 50 $\mathrm{m}$ intervals. Ten $0.25 \mathrm{~m}^{2}$ plots were located $1 \mathrm{~m}$ from the transect at $5 \mathrm{~m}$ intervals, alternating sides (Fig. 2).

\section{Collection and identification of echinoderm species}

Echinoderms present within each quadrat were recorded. Two to three representative samples per species were collected using tweezers and sticks and were placed in containers with $10 \%$ formaldehyde solution. The collected and preserved samples were used for further identification in the laboratory. Morphology was used for identification
(Clark, Rowe 1971; Barnes 1987; Vandenspiegel et al. 1998; Schoppe 2000; Stöhr et al. 2012; Pechenik 2015).

\section{Data analysis}

Relative abundance is the proportion of a species in an ecosystem or sample of a community. The relative abundance $\left(p_{i}\right)$ of each species was expressed as

$$
p_{i}=n_{i} / N \times 100 \text {, }
$$

where $n_{i}$ is the number of individuals of the same species and $N$ is the total number of individuals for all species.

Coefficient of dispersion $(C D)$ is a measure used to quantify whether a set of organisms are clustered or dispersed (Walag, Canencia 2016). It was expressed as

$$
C D=\text { variance / mean; }
$$

where $C D$ lesser than $1(<1)$ is regular/uniform, greater than $1(>1)$ is clumping, equal to $1(=1)$ is random.

The Shannon diversity index $H^{\prime}$ (Margalef 1957) and evenness $J^{\prime}$ (Pielou 1975) were calculated.

\section{Results and discussion}

\section{Species composition and abundance}

Three hundred eighty seven (387) individuals were collected along the intertidal zone of Babanlagan, Talisayan, Misamis Oriental at three sampling times in September 2015 from four classes of echinoderms (Echinoidea, Holothuroidea, Asteroidea, and Ophiuroidea). The majority of the individuals (Fig. 3) belonged to class Asteroidea with relative abundance $64 \%$, followed by Echinoidea (24\%), Holothuroidea (11\%), and Ophiuroidea (1\%). Similar results were obtained in a study conducted by Alvarado et al. (2012) in the Gulf Chiriqui, Panama, where the majority of echinoderms collected were in class Asteroidea and Echinoidea. Asteroidea and Echinoidea abundance can be attributed to the higher coral diversity and cover, which

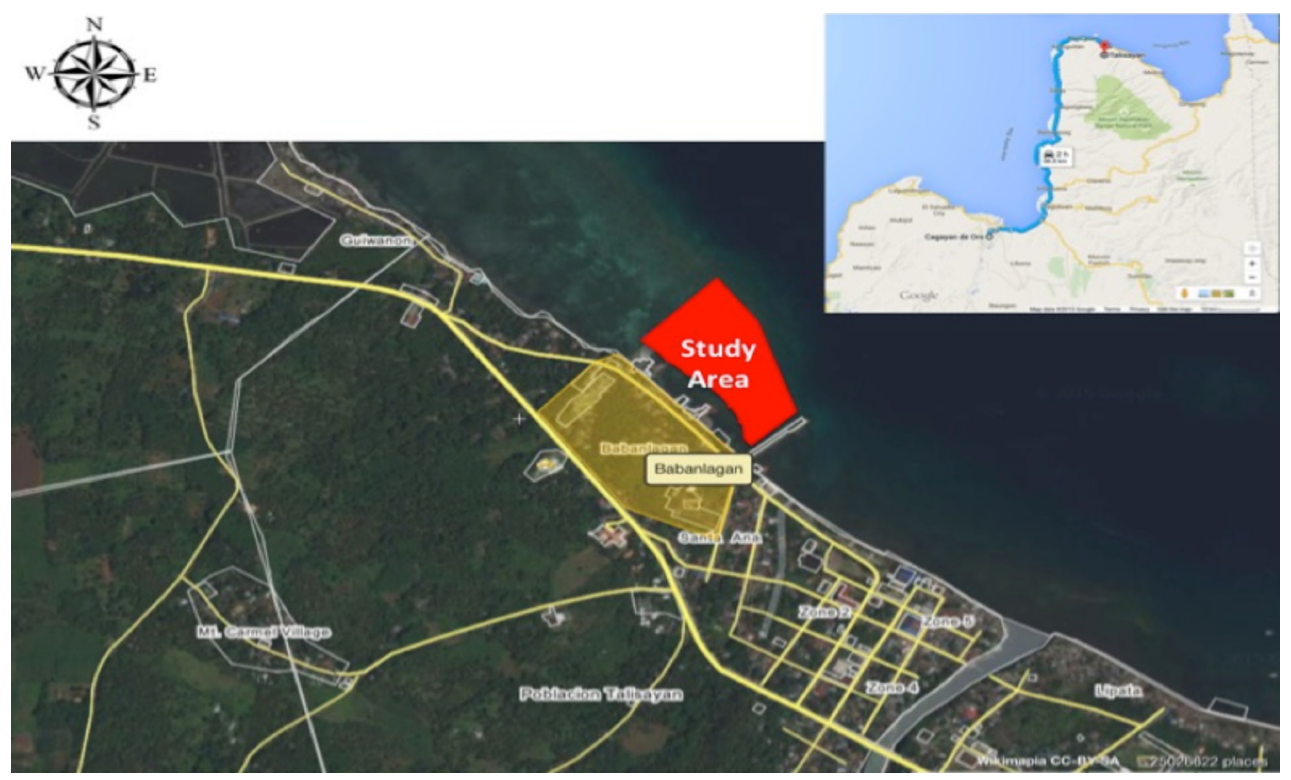

Fig. 1. Location of study area at Babanlagan, Talisayan, Misamis Oriental, Philippines. 


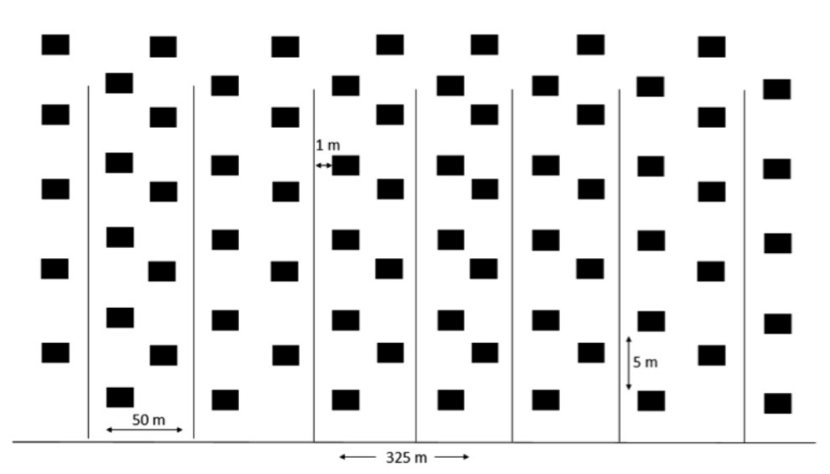

Fig. 2. Establishment of transects and plots in the study area.

can serve as both food and habitat for these organisms. Any impact to the coralline environment can directly affect the abundance of these classes of echinoderm corallivores (Alvarado et al. 2012). Low diversity can be caused by various anthropogenic activities that affect the intertidal zone like waste disposal from coastal communities in the study area, gleaning activities of locals during low tide, and habitat destruction due to active fishing.

The collected 387 individuals belonged to 10 taxa of echinoderms (Table 1). The most abundant species was Protoreaster nodusus Linnaeus, 1758 with relative abundance of $30.75 \%$ while the least abundant species was Acanthaster planci Linnaeus, 1758 with relative abundance $0.78 \%$. P. nodusus is common in the tropics of Indo-Pacific regions (Bos et al. 2008; Scheibling, Metaxas 2008). It has also been actively collected and harvested by locals as ornaments but this was not observed in the study area, which may explain its relatively high abundance (Bos et al. 2008; Scheibling, Metaxas 2008). P nodusus prefers shallow habitats dominated by sea grasses (Bos et al. 2008) which also explains its abundance in the intertidal zone of the study area. A. planci is a major coral predator, usually abundant in the Pacific Ocean (Chesher 1969; Fabricius et al.2010; Alvarado et al. 2012). Even though there have been reports of large population densities of A. planci causing increased coral destruction, low relative abundance was

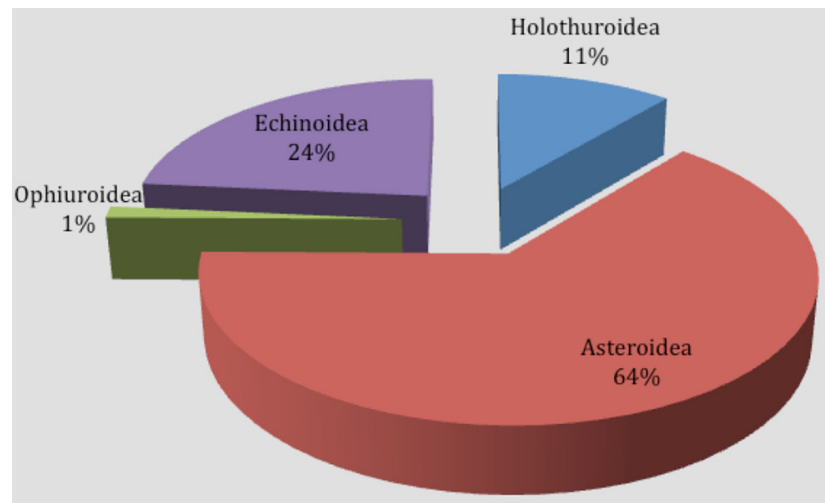

Fig. 3. Relative abundance of echinoderm families in Babanlagan Misamis Oriental, Philippines. observed in the study area, which may be due to its narrow temperature tolerance range (Johnson, Babcock 1994). In the study area the temperature ranged from 28 to $32{ }^{\circ} \mathrm{C}$, which is beyond the tolerance of $A$. planci. High mortality rates were also observed due to predation; due to its small size it might be vulnerable as prey, but actual predation was not observed (Keesing et al. 1996).

Ophiomastix sp. and Nardoa tuberculata were found to be least abundant in the study conducted. Ophiomastix sp., although readily observable, can easily hide and escape, as it moves quickly and can easily hide under rocks and sediment (Walag, Canencia 2016). This might explain the low abundance. The low abundance of $N$. tuberculata may be due to its preference for deeper habitats $>3 \mathrm{~m}$ (Bos et al. 2008).

\section{Coefficient of dispersion}

The distribution pattern of each echinoderm species was determined using the coefficient of dispersion as used by Walag and Canencia (2016). From the 10 species collected, Synapta sp., Linckia laevigata, Archaster typicus, Pentaster obstusatus, A. planci, Tripneustes gratilla, and Diadema setosum exhibited clumped distributions while the other three species (Protoreaster nodosus, N. tuberculata and Ophiomastix sp.) exhibited regular or uniform dispersion. The clumped distribution may be explained by limited dispersal ability and spatial variation of habitat availability, particularly for members of the Asteroidea family (Medrano 2015). Synapta sp. exhibits a clumped pattern due to behaviour of hiding in reefs, or among rocks and rubble, seagrasses, and weeds (James 2001). Though A. planci exhibited a clumped spatial pattern, the data cannot be relied on statistically due to limited number of observations. The low abundance of $A$. planci in the area can be explained by low cover of corals, which serves as food and habitat for these organisms. Their aggregating are easily seen in coral reefs feeding on colonies of corals in shallows (Moran 1988).

Ophiomastix sp. showed a regular distribution (Table 1 ), but brittle stars tend to have clumped pattern due to availability of food (Schoppe 2000). T. gratilla and D. setosum are collector/grazer urchins and normally feed on a variety of seagrasses or algae, which can explain their clumped distribution in the seagrass part of the study area. $P$. nodusus generally has a clumped distribution, due to association with seagrasses and macroalgae (Scheibling, Metaxas 2008) but in this study they had a regular/uniform distribution. This might be due to its reproductive strategy which involves migrating often to specific depths (Bos 2008). These sea stars travel away from the intertidal zone during spawning to avoid risk of being reproductively isolated during low tide. Various environmental factors and ecological processes drive different distribution patterns of echinoderms, thus making generalizations about the patterns difficult (Iken et al. 2010). 
Table 1. Species composition, relative abundance, coefficient of dispersion, species diversity and evenness of echinoderms in Babanlagan, Misamis Oriental, Philippines. N, number of individuals; RA, relative abundance; CD, coefficient of dispersion. ${ }^{*}$ clumped; ${ }^{\star *}$ regular/ uniform

\begin{tabular}{|c|c|c|c|c|}
\hline Class & Species & $\mathbf{N}$ & RA & CD \\
\hline Holothuroidea & Synapta sp. & 43 & 11.11 & $1.67^{\star}$ \\
\hline \multirow[t]{6}{*}{ Asteroidea } & Linckia laevigata Linnaeus, 1758 & 54 & 13.95 & $1.13^{*}$ \\
\hline & Archaster typicus Müller \& Troschel, 1840 & 36 & 9.30 & $1.11^{\star}$ \\
\hline & Pentaster obtusatus Bory de St. Vincent, 1827 & 29 & 7.49 & $1.22^{*}$ \\
\hline & Protoreaster nodusus Linnaeus, 1758 & 119 & 30.75 & $0.77^{\star *}$ \\
\hline & Nardoa tuberculata Gray, 1840 & 7 & 1.81 & $0.91^{* *}$ \\
\hline & Acanthaster planci Linnaeus, 1758 & 3 & 0.78 & $1.20^{*}$ \\
\hline Ophiuroidea & Ophiomastix sp. & 5 & 1.29 & $0.94^{* *}$ \\
\hline \multirow[t]{2}{*}{ Echinoidea } & Tripneustes gratilla Linnaeus, 1758 & 17 & 4.39 & $1.13^{*}$ \\
\hline & Diadema setosum Leske, 1778 & 74 & 19.12 & $2.05^{\star}$ \\
\hline Total & & 387 & 100 & \\
\hline Species diversity & 1.92 & & & \\
\hline Species evenness & 0.68 & & & \\
\hline
\end{tabular}

\section{Species diversity and evenness}

Species diversity was calculated for the seven transects using the Shannon Index of Diversity (Margalef 1957) and species evenness (Pielou 1975). The mean Shannon diversity of echinoderms in Babanlagan, Talisayan, Misamis Oriental was $H^{\prime}=1.92$ which is moderately diverse. This diversity can be explained by the availability of corals, rocks, and seagrasses, which can serve both as food and habitat for echinoderms. Though the health of the corals and seagrasses is not optimum, the habitat still aids in supporting echinoderm population. Species evenness was $J^{\prime}=0.68$, which denotes moderate variation between organisms in abundance.

\section{Conclusion}

The distribution and diversity of echinoderms in Babanlagan, Talisayan, Misamis Oriental were determined. Echinoderm species were collected and identified and further analysis was done to determine their distribution pattern, relative abundance, species diversity, and evenness. A total of 387 individuals were collected, representing four classes of the phylum Echinodermata. Ten species were identified. The most abundant was $P$. nodusus. The study area supported moderate diversity and there was moderate variation in abundance among species in the community. Although the study area faces dayto-day threats from active fishing, gleaning, and habitat destruction, various echinoderms still exist. It is also good to note the prevalence of $P$. nodusus, which is considered to be a good indicators of coralline health, and the presence of a commercially important echinoderm species, $T$. gratilla, which signals that exploitation of marine resources is not very alarming. The low abundance of some species might be attributed to collection and trading, like that of $L$. laevigata. Furthermore, it is recommended that follow-up studies, especially monitoring of echinoderm species, must be conducted to further assess the health of the intertidal zone in Babanlagan, Talisayan, Misamis Oriental.

\section{References}

Alvarado J.J., Guzman H.M., Breedy O. 2012. Distribution and diversity of echinoderms (Asteroidea, Echinoidea, Holothuroidea) in the islands of the Gulf of Chiriqui, Panama. Rev. Biol. Mar. Ocean. 47: 13-22.

Barnes R.D. 1987. Invertebrate Zoology. $5^{\text {th }}$ ed. Harcourt Brace Jovanovich College Publishers, Fort Worth.

Bos A.R., Gumanao G.S., Alipoyo J.C.E., Cardona L.T. 2008. Population dynamics, reproduction and growth of the IndoPacific horned sea star, Protoreaster nodosus (Echinodermata; Asteroidea). Mar. Biol. 156: 55-63.

Bos A.R., Alipoyo, J.C.E., Cardona L.T., Gumanao G.S., Salac F.N. 2008. Population structure of common Indo-Pacific sea Stars in the Davao Gulf, Philippines. UPV J. Nat. Sci. 13: S11-S24

Campbell N.A., Reece J.B. 2008. Biology. $8^{\text {th }}$ Ed. Pearson/Benjamin Cummings, San Francisco.

Chesher R.H. 1969. Destruction of Pacific Corals by the Sea Star Acanthaster planci. Science 165: 280-283.

Clark A.M., Rowe F.W.E. 1971. Monograph of Shallow-water IndoWest Pacific Echinoderms. Pitman Press, Bath.

Dolorosa R.G. 2015. The sea cucumbers (Echinodermata: Holothuroidea) of Tubbataha Reefs Natural Park, Philippines. Beche-de-mer Information Bulletin 35: 10-18.

Dupont S., Ortega-Martínez O., Thorndyke M. 2010. Impact of near-future ocean acidification on echinoderms. Ecotoxicology 19: 449-462.

Ellis J.R., Rogers S.I. 2000. The distribution, relative abundance and diversity of echinoderms in the eastern English Channel, Bristol Channel, and Irish Sea. J. Mar. Biol. Assoc. UK 80: 127138.

Fabricius K.E., Okaji K., De'ath G. 2010. Three lines of evidence to link outbreaks of the crown-of-thorns seastar Acanthaster planci to the release of larval food limitation. Coral Reefs 29: 593-605.

Iken K., Konar B., Benedetti-Cecchi L., Cruz-Motta J.J., Knowlton 
A., Pohle G., Mead A., Miloslavich P., Wong M., Trott T., Mieszkowska N., Riosmena-Rodriguez R., Airoldi L., Kimani E., Shirayama Y., Fraschetti S., Ortiz-Touzet M., Silva A. 2010. Large-scale spatial distribution patterns of echinoderms in nearshore rocky habitats. PLOS ONE 5: e13845.

James D.B. 2001. Twenty sea cucumbers from seas around India. Naga The ICLARM Quarterly 24: 4-8.

Johnson L.G., Babcock R.C. 1994. Temperature and the larval ecology of the crown-of-thorns starfish, Acanthaster planci. Biol. Bull. 187: 304-308.

Keesing J.K., Wiedermeyer W.L., Okaji K., Halford A.R., Hall K.C., Cartwright C.M. 1996. Mortality rates of juvenile starfish Acanthaster planci and Nardoa spp. measured on the Great Barrier Reef, Australia and in Okinawa, Japan. Oceanol. Acta 19: 441-448.

Lawrence J.M., Herrera J. 2000. Stress and deviant reproduction in echinoderms. Zool. Stud. 39: 151-171.

Margalef R. 1957. La teoria de la informacion en ecologia. Mem. Real Acad. Cienc. Artes Barcelona 32: 373-449.

Md Rawi C.S., Al-Shami S.A., Madrus M.R., Ahmad A.H. 2014. Biological and ecological diversity of aquatic macroinvertebrates in response to hydrological and physicochemical parameters in tropical forest streams of Gunung Tebu, Malaysia: implications for ecohydrological assessment. Ecohydrology 7: 496-507.

Medrano M.G.T. 2015. Diversity of macrobenthic invertebrates in the intertidal zone of Brgy. Tagpangahoy, Tubay, Agusan del Norte, Philippines. Int. J. Techn. Res. Appl. 19: 5-9.

Moran P. 1988. The Acanthaster phenomenon. Australian Institute of Marine Science Monograph Series 7: 379-480.

Pechenik J.A. 2015. Biology of Invertebrates. $5^{\text {th }}$ Ed. McGraw-Hill
Publishing, New York.

Pielou E.C. 1975. Ecological Diversity. John Wiley \& Sons, New York.

Rajakumar C.P., Ebanasar J. 2008. Diversity and population dynamics of echinoderms from Muttom and Colachel coasts in south west coast of India. J. Basic Appl. Biol. 2: 69-82.

Scheibling R.E., Metaxas A. 2008. Abundance, spatial distribution, and size structure of the sea star Protoreaster nodosus in Palau, with notes on feeding and reproduction. Bull. Mar. Sci. 82: 221-235.

Schoppe S. 2000. Echinoderms of the Philippines: a guide to common shallow water sea stars, brittle stars, sea urchins, sea cucumbers and feather stars. VISCA-GTZ Program on Applied Tropical Ecology, Visayas State College of Agriculture, Philippines.

Souto V., Escolar M., Genzano G., Bremec C. 2014. Species richness and distribution patterns of echinoderms in the southwestern Atlantic Ocean (34-56 S). Sci. Mar. 78: 269-280.

Stöhr S., O'Hara T.D., Thuy B. 2012. Global diversity of brittle stars (Echinodermata: Ophiuroidea). PLoS ONE 7:e31940.

Ubaldo J.P., Uy F.A., Dy D.T. 2007. Temperature tolerance of some especies of Philippine intertidal echinoderms. Philipp. Sci. 44: 105-119.

VandenSpiegel D., Lane D.J.W., Stampanato S., Jangoux M.1998. The asteroid fauna (Echinodermata) of Singapore, with a distribution table and an illustrated identification to the species. Raffles Bull. Zool. 46: 431-470.

Walag A.M.P., Canencia M.O.P. 2016. Physico-chemical parameters and macrobenthic invertebrates of the intertidal zone of Gusa, Cagayan de Oro City, Philippines. AES Bioflux 8: 71-82. 